\title{
Model Prediction of Particulate Dispersion from a Cement Mill Stack: Case Study of a Cement Plant In Nigeria
}

\author{
${ }^{1}$ Otaru, A.J., ${ }^{2}$ Odigure, J.O., ${ }^{3}$ Okafor, J.O. And ${ }^{4}$ Abdulkareem, A.S. \\ ${ }_{1,2 \& 3}$ (Department of Chemical Engineering, Federal Univeristy of Technology, PMB 065, Gidan \\ Kwanu, Minna, Niger State, Nigeria). \\ (Published with the support of Zeno Karl Schindler Foundation)
}

\begin{abstract}
This research work was necessitated as a result of high pollution rate of particulate matters within and outside cement plants in Nigeria. The study plans to applied Gaussian predictive model to quantify the concentration of particulate dispersion from a cement mill stack and to identify a safety distance for human settlement and activities. The meteorological concentrations of particulate matter have been measured using the SKC deployable particulate sampler both in the plant and far away from the cement mill stack. Concentration of Particulate matter was computed using the formulated Gaussian plume model that incorporates meteorological and source related factors to estimate particulates' concentration downwind from a cement mill stack. The simulated results are in agreement with the experimental results at an average value of $92 \%$ within a Gaussian distance of $200-2,000 \mathrm{~m}$. The simulated results of this work shows that the concentrations in the ambient air at a distance of about $1.5-4.5 \mathrm{~km}$ from the stack is higher than the World Health Organisation standard annual average value of $260 \mu \mathrm{g} / \mathrm{m}^{3}$ and $2.0-4.0 \mathrm{~km}$ from the stack was also higher than the Nigerian Federal Ministry of Environmental standard annual average value of $500 \mu \mathrm{g} / \mathrm{m}^{3}$. Due to other fugitive emissions from cement plants, a simulated safety distance beyond $7.0 \mathrm{~km}$ from the plant is recommended for human settlement and activities.
\end{abstract}

Key words: Air pollution, Cement plant, Gaussian plume model, Nigeria and Particulate matter.

\section{Introduction}

The productions of cement involve crushing, homogenization, raw milling, calcining and burning, and cement milling. Cement manufacture causes environmental impacts at all stages of the process. These include emission of airborne pollution in the form of dust, gases, noise and vibration when operating machinery and blasting in quarries. In some circumstances, mainly depending on the origin and the composition of the raw materials used, the high temperature calcination of limestone can release into the atmosphere gases and dust rich in volatile heavy metals like thalium, cadium and mercury. These heavy metals are often found as trace elements in common metal sulfides (Iron Sulfide $\mathrm{FeS}_{2}$, Zinc Sulfide $\mathrm{ZnS}$, and Lead Sulfide PbS) present as secondary minerals in most of the raw materials. Environmental regulations exist in many countries to limit these emissions (WBCSD, 2005).

When air pollution began to have significant deleterious effects on human life, it become necessary to discover and understand the link between emission sources and the air quality deterioration and health effects they cause. Only after the impacts of sources have been assessed correctly will it be possible to devise and implement rational, convincing, and effective policies to improve air quality (Armistead, 1988). Section 27, NESREA ACT 2007 of the constitution of the Federal Republic of Nigeria prohibits, without lawful authority, the discharge of hazardous substances into the environment. This offence is punishable under this section, with a fine not exceeding one million naira and an imprisonment of 5 years. In the case of a company, there is an additional fine of N50, 000.00, for everyday the offence persists (www.elri-ng.com). If a fraction of those expenses can be saved by better understanding of the relation of air quality and the health effects to emission sources, the monetary benefits will be tremendous. Knowledge of the relation between emissions by a source and pollutant concentrations in the air at later times and other places (i.e source/receptor relationship) is essential to calculating the exposure of humans to these pollutants and hence to predicting the health impacts resulting from these emissions. Mathematical models have evolved as the most practical means to relate source emissions to the subsequent air pollution concentration (Armistead, 1988).

The need to study industrial air pollution and to take a critical and in-depth investigation into pollutants concentration resulting from particulate emissions is of global concern because of the damaging effects of these pollutants on the environment (Abdulkareem and Odigure, 2009). Secondly, the steps of raw material processing, fuel preparation, clinker burning and cement grinding constitute major emission sources of particulate components. While emission limit for particulate matter from a cement plant as set by the World Health Organization (WHO) in her guideline and standards for ambient air quality stipulates legal limits of $50 \mathrm{mg} / \mathrm{m}^{3}$, today much lower levels are achievable (Bala, 2003). Lastly, the need to avert the negative impacts 
of industrial emissions has made the study of emission problems to feature very prominently in the development strategies of many developing and developed countries and this called for the attention of industry and academia to finding way to curbing it. Motivated by the above observations, this paper focused on the formulation of a predictive model for determination of particulate dispersion from a cement mill stack.

Several model equations have been developed for determining the concentration of air pollutants, most importantly is the Gaussian Dispersion model. Gaussian Dispersion model is widely used to predict gaseous pollutant concentration. The incorporation of source related and local factors in the Gaussian Model make it more suitable in predicting particulate concentration with minimal deviation. Therefore, this research work focuses on the adaptation of the Gaussian model to determine the downwind concentration of particulate matters from a cement mill stack.

For a variety of factors, no two cement plants are alike in design or operation. Invariably, there will be one or more plants that will differ in some aspects from the generalizations presented herein. A cement producing company in Nigeria was taken as a case study.

\section{Research Methodology And Working Model}

There are various methods of detecting or monitoring air pollution in the environment. But these experimental methods are capital intensive; hence only large or well established industries can afford them. The In Stack Iso-Kinetic Sampling method was employed in the cement stacks using the Vayuboden Stack Sampler (VSS). Iso-Kinetic Sampling means sampling in which the linear velocity of the gas entering the sampling nozzle is equal to that of the undisturbed gas stream at the sampling point. Sampling made in this way has the advantage of all the substances in the sample having same motion/movement in terms of force, speed, and direction. The sampling method conducted at any receptor location is the PM10 particulate sampling.

\subsection{Sampling}

The sampling was conducted by the Health and Safety staff of ESP mechanical department of the cement plant. Samplings are usually conducted two or three times in a month both inside and at a distance of 5 $\mathrm{km}$ away from the plant depending on the atmospheric conditions. This was carried out by replacing representative sample media used for calibration with new, pre-weighed media. Bracket was mounted at the desired location and at the breathing zone ( $6 \mathrm{ft}$ or $2 \mathrm{~m}$ ) using wire ties or other fasteners. Impactor was mounted on screw on mounting brackets.

The screw was inserted on cap into screw hole in top of Impactor inlet and rotating the cap until it is tight. The pump was turn on and proper recording of sample start time, ambient temperature, ambient pressure, and other pertinent were done. After desired sample time has elapsed, the pump was turn off and sample stops time, total volume, ambient temperature, ambient pressure, and other pertinent data were recorded. The cap was removed, the calibration train was reinstated, and flow rate verified. Quick-disconnect on case were used to remove tubing from pump. Tubing and cap were removed from Impactor. The meteorological sample results obtained are presented in Appendix V.

\subsection{Working Model}

Equation (1) is an established Gaussian model equation and serves as the working model. Evaluation of source and meteorological parameters are needed for effective programming and prediction of the particulate concentration. Some of the basic parameters are wind velocity $(\overline{\mathrm{u}})$, bagfilter efficiency $(\varepsilon)$, crosswind distance $\left(\sigma_{\mathrm{y}}\right)$, source height $(\mathrm{g})$, stacks gas flow rate $(\mathrm{Q})$, and particle density $(\rho)$.

$C=\frac{Q}{\overline{\mathrm{u}}} \cdot \frac{W}{\sigma_{\mathrm{y}} \sqrt{2 \pi}} \cdot \frac{\mathrm{g}_{1}+\mathrm{g}_{2}+\mathrm{g}_{3}}{\sigma_{\mathrm{z}} \sqrt{2 \pi}}$

\subsubsection{Wind velocity}

The wind velocity used in the Gaussian dispersion equations should be the velocity which prevails throughout the vertical and crosswind spread of the plume. This creates a dilemma in that;

I. The derivation of the generalized Gaussian dispersion equation assumes a constant wind velocity throughout the plume, and

II. The wind velocity is not constant throughout the plume since it typically varies with altitude.

Thus, as a minimum requirement, the wind velocity used in the Gaussian dispersion equation should be determined at the emission height (or the so called "effective stack height He") for a given downwind distance (Beychok, 2005).

The mean wind speed variation with altitude in the planetary boundary layer can be represented by a simple empirical power law such as (Rao, 2006). 
$\frac{\overline{\mathrm{u}}}{\overline{\mathrm{u}}_{1}}=\left(\frac{\mathrm{z}}{\mathrm{z}_{1}}\right)^{\propto}$

$\bar{u}=$ the average wind speed at the stack height Hs. Equation (2) can be evaluated by modifying the velocity profile expression on given below as

$\frac{\bar{u}}{\bar{u}_{1}}=\left(\frac{\mathrm{H}_{\mathrm{s}}}{\mathrm{z}_{1}}\right)^{\propto}$

$\bar{u}_{1}=$ the meteorological value of the velocity measured at $\mathrm{z}_{1}=10$ meters.

$\frac{\bar{u}_{1}}{\bar{u}}=\left(\frac{\mathrm{z}_{1}}{\mathrm{H}_{\mathrm{s}}}\right)^{\propto}$

$\propto$ is a function of the surface area roughness. $\propto \approx 0.25-5.0$ from unstable to stable condition (Beychok, 1995).

The average wind speed is obtained from the table below:

Table 1: Pasquill stability class related to wind speed and insulation (Beychok, 1995)

\begin{tabular}{|c|c|c|c|c|c|}
\hline \multirow{2}{*}{$\begin{array}{l}\text { Wind speed } \\
(\mathrm{m} / \mathrm{s})(\text { at } \\
\mathrm{z}=10 \mathrm{~m})\end{array}$} & \multicolumn{3}{|c|}{ Day - time insolation } & \multicolumn{2}{|c|}{ Night - time cloud cover } \\
\hline & Strong & Moderate & Slight & $>4 / 8$ Cloud & $<3 / 8$ Cloud \\
\hline$<2$ & A & $A-B$ & B & - & - \\
\hline $2-3$ & $A-B$ & B & $\mathrm{C}$ & $\mathrm{E}$ & $\mathrm{F}$ \\
\hline $3-5$ & B & $\mathrm{B}-\mathrm{C}$ & $\mathrm{C}$ & $\mathrm{D}$ & $\mathrm{E}$ \\
\hline $5-6$ & $\mathrm{C}$ & $C-D$ & $\mathrm{D}$ & $\mathrm{D}$ & $\mathrm{D}$ \\
\hline$>6$ & $\mathrm{C}$ & $\mathrm{D}$ & $\mathrm{D}$ & $\mathrm{D}$ & $\mathrm{D}$ \\
\hline
\end{tabular}

A: Extremely unstable, B: Moderately unstable, C: Slightly unstable, D: Neutral conditions

E: Slightly stable, F: Moderately stable.

\subsubsection{Determination of crosswind (y) distance}

The determination of crosswind distance can be determined by the use of Pythagoras theorem indicated in Figure 1. The downwind, crosswind, vertical and radial distances are denoted by letter $\mathrm{x}, \mathrm{y}, \mathrm{z}$ and $\mathrm{R}$.

From Figure 1, the radial distance is given as

$\mathrm{R}=\left(\mathrm{x}^{2}+\mathrm{y}^{2}\right)^{1 / 2}$

$\mathrm{R}=$ Radial distance

$\mathrm{x}=$ Downwind distance

$\mathrm{y}=$ Crosswind distance

The crosswind distance y is calculated as

$\mathrm{y}=\mathrm{R} \sin \theta$

$\theta=$ the sector width.

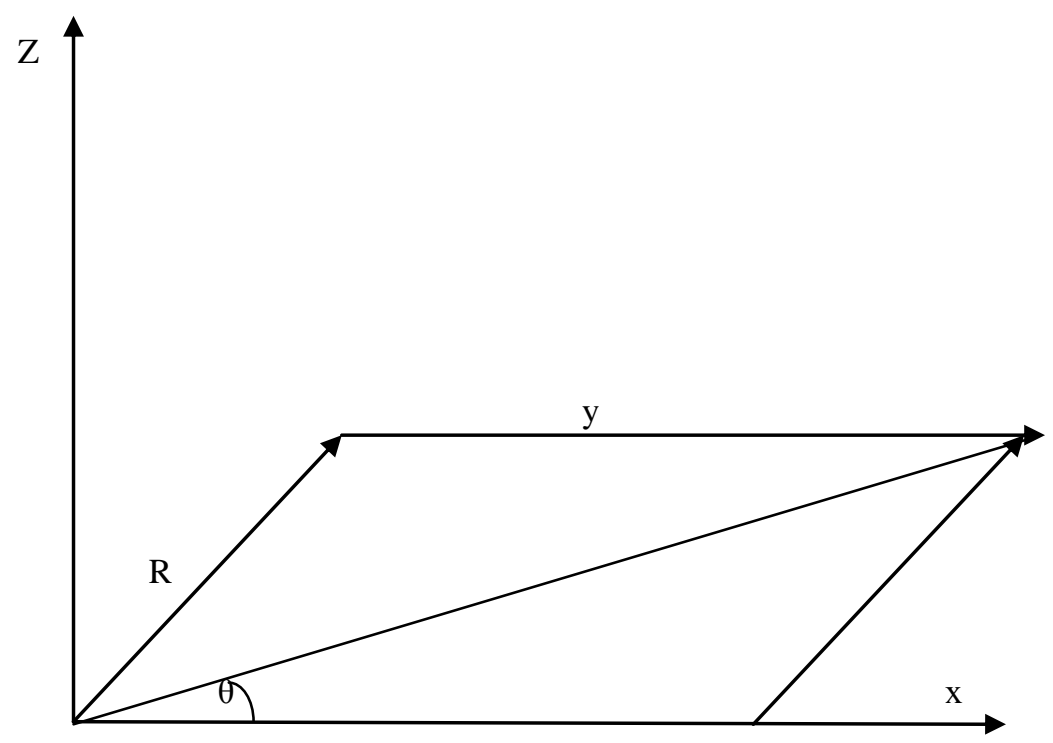

Figure 1: Schematic representation of crosswind, radial and horizontal distances in a plane.

For a complex terrain, the sector average approach used implies that the lateral (crosswind) distribution of concentrations is uniform across a $22.5^{\circ}$ sector. The complex terrain screening algorithm applies only to a point 
source and volume source emission. Area source and open pit emission source are excluded (Karl \& Partha, 2000).

Hence, from equation (6)

$\mathrm{R}=\left(\frac{\mathrm{y}}{\sin \theta}\right)$

$\mathrm{R}^{2}=\left(\frac{\mathrm{y}}{\sin \theta}\right)^{2}=\mathrm{x}^{2}+\mathrm{y}^{2}$

$\mathrm{x}^{2}+\mathrm{y}^{2}=\left(\frac{\mathrm{y}}{\sin \theta}\right)^{2}$

For known value of downwind distance (x), the radial distance (R) and Crosswind distance (y) are calculated from equation (5), (6) and (7) using Microsoft excel.

\subsubsection{Incorporating bagfilter efficiency into the dispersion model}

Collecting efficiency

The ability of a dust collector to remove particulate from the exhaust gas is termed as collecting efficiency. The ratios of particles entering the collection devise Vs particles' leaving is expressed in percent.

Collection efficiency $=\frac{\text { Inlet loading }- \text { Outlet loading }}{\text { Inlet loading }} * 100$

NB: Collector - used interchangeably with "baghouse", "cartridge filter", or mechanical collector, as in "cyclone" (www.slyfilters.com).

The efficiency of a bagfilter depends on time and pressure drop. Some bagfilter could last for 8-10 months before replacement. The bagfilter used in the cement mill is the high efficiency $(94-99 \%)$ pulse jet filter (PJF) which last for 8 months before replacement (Smidth, 2006).

The static pressure drop across a fabric filter system is important for several reasons. Lower - than - normal static pressure drop indicates that there may be insufficient dust cake thickness, resulting in reduced collection efficiency. Higher than - expected static pressure drop increases the overall system resistance to gas flow. Decreased gas flow from the process area will result if the centrifugal fan and damper system cannot compensate for this increased resistance. Fugitive emissions can occur when the gas flow rate at the hood is too low. High static pressure drop also increases the electrical energy needed for the centrifugal fan, increasing the operating costs for the system (Weber \& Schelkoph, 1990). In the cement mills, the bagfilter differential pressure is recorded to be within the range of $10-11.4 \mathrm{hpa}$ (Smidth, 2006).

In incorporating the bagfilter efficiency $\varepsilon$, the source strength $Q$ is a function of particle density $\rho_{p}$, source volume flow rate $\tilde{V}_{s}$ and stack efficiency. Table 2 is a tabular representation of the molecular weight and percentage compositions of the PM10 which is used in calculating it source volume flow rates.

Table 2: Molecular weight and percentage compositions of PM10 from the cement mill stack (Smidth, 2006).

\begin{tabular}{cccc}
\hline S/No & Composition of PM10 & Molecular weight $(\mathrm{g} / \mathrm{mol})$ & Percentage composition $(\%)$ \\
\hline 1. & $\mathrm{SiO}_{2}$ & 60.0844 & 21.060 \\
2. & $\mathrm{Al}_{2} \mathrm{O}_{3}$ & 101.9614 & 4.545 \\
3. & $\mathrm{Fe}_{2} \mathrm{O}_{3}$ & 159.6887 & 4.000 \\
4. & $\mathrm{CaO}$ & 56.0778 & 68.740 \\
5. & $\mathrm{MgO}$ & 40.3045 & - \\
6. & $\mathrm{SO}_{3}$ & 80.0638 & 1.660 \\
7. & $\mathrm{~K}_{2} \mathrm{O}$ & 94.1960 & - \\
8. & $\mathrm{Na}_{2} \mathrm{O}$ & 61.9790 & - \\
\hline
\end{tabular}

The source emission rate or source strength $Q,(\mathrm{~g} / \mathrm{s})$ is given as:

$\mathrm{Q}=\rho_{\mathrm{p}} \square_{\mathrm{s}}$

Calculating the volume of each component of the pollutants emitted.

Basis $=1 \mathrm{~m}^{3}$ of PM10 emitted.

From table 2 above, the percentage of $\mathbf{S i O}_{2}=21.06 \%$

$\mathrm{V}_{1}=\frac{21.06}{100} * 1 \mathrm{~m}^{3}=0.2106 \mathrm{~m}^{3}$.

Let $\varepsilon=$ the bagfilter efficiency

The efficiency of bagfilter is inversely proportional to the volume of PM10 exiting the stack (Smidth, 2006). Therefore, $\square_{1}=1 / \square * 0.2106 \mathrm{~m}^{3}=0.2106 / \varepsilon\left(\mathrm{m}^{3}\right)$

For $\mathrm{Al}_{2} \mathrm{O}_{3}$ 
$\mathrm{V}_{2}=\frac{4.545}{100} * 1 \mathrm{~m}^{3}=0.04545 \mathrm{~m}^{3}$

Therefore, $\square_{2}=1 / \square * 0.04545 \mathrm{~m}^{3}=0.04545 / \varepsilon\left(\mathrm{m}^{3}\right)$

For $\mathrm{Fe}_{2} \mathrm{O}_{3}$

$\mathrm{V}_{3}=\frac{4.00}{100} * 1 \mathrm{~m}^{3}=0.040 \mathrm{~m}^{3}$

Therefore, $\square_{3}=1 / \square * 0.040 \mathrm{~m}^{3}=0.040 / \varepsilon\left(\mathrm{m}^{3}\right)$

For $\mathrm{CaO}$

$\mathrm{V}_{4}=\frac{68.74}{100} * 1 \mathrm{~m}^{3}=0.6874 \mathrm{~m}^{3}$

Therefore, $\square_{4}=1 / \square * 0.6874 \mathrm{~m}^{3}=0.6874 / \varepsilon\left(\mathrm{m}^{3}\right)$

For MgO

$\mathrm{V}_{5}=\frac{0}{100} * 1 \mathrm{~m}^{3}=0.000 \mathrm{~m}^{3}$

Therefore, $\square_{5}=1 / \square * 0.00 \mathrm{~m}^{3}=0.000 / \varepsilon\left(\mathrm{m}^{3}\right)$

\section{For $\mathrm{SO}_{3}$}

$\mathrm{V}_{6}=\frac{1.660}{100} * 1 \mathrm{~m}^{3}=0.0166 \mathrm{~m}^{3}$

Therefore, $\square_{6}=1 / \square * 0.0166 \mathrm{~m}^{3}=0.0166 / \varepsilon\left(\mathrm{m}^{3}\right)$

For $\mathrm{Na}_{2} \mathrm{O}$

$\mathrm{V}_{7}=\frac{0}{100} * 1 \mathrm{~m}^{3}=0.000 \mathrm{~m}^{3}$

Therefore, $\square_{7}=1 / \square * 0.00 \mathrm{~m}^{3}=0.00 / \varepsilon\left(\mathrm{m}^{3}\right)$

For $\mathrm{K}_{2} \mathrm{O}$

$\mathrm{V}_{8}=\frac{0}{100} * 1 \mathrm{~m}^{3}=0.000 \mathrm{~m}^{3}$

Therefore, $\square_{8}=1 / \square * 0.00 \mathrm{~m}^{3}=0.000 / \varepsilon\left(\mathrm{m}^{3}\right)$

The source emission rate is calculated as:

$\square_{\mathrm{s}}=\sum_{\mathrm{i}=1}^{8} \square_{\mathrm{i}} * \mathrm{~V}_{\mathrm{s}}=(1.00 / \varepsilon) * \mathrm{~V}_{\mathrm{s}}$

(10)

Where $V_{s}$ is the stack gas volumetric flow rate $\left(\mathrm{m}^{3} / \mathrm{s}\right)$

Thus, from equation (9),

$\mathrm{Q}=\rho_{\mathrm{p}} * \square_{\mathrm{s}}$

Substituting equation (10) into equation (8), we then have:

$\mathrm{Q}=(1.00 / \varepsilon) * \rho_{\mathrm{p}} * \mathrm{~V}_{\mathrm{s}}$

Hence, the formulated model equation for the particulate matter emitted from a cement mill stack is given below as:

$C=\left\{\frac{(1 / \varepsilon) \rho_{\mathrm{p}} \mathrm{V}_{\mathrm{s}}}{\overline{\mathrm{u}}_{1} \sigma_{\mathrm{y}} \sqrt{2 \pi}}\right\} \cdot \exp \left[\frac{-1}{2}\left(\frac{\mathrm{y}}{\sigma_{\mathrm{y}}}\right)^{2}\right] \cdot\left[\frac{\mathrm{g}_{1}+\mathrm{g}_{2}+\mathrm{g}_{3}}{\sigma_{\mathrm{z}} \sqrt{2 \pi}}\right]$

$\mathrm{C}=$ Concentration of emission, $\mu \mathrm{g} / \mathrm{m}^{3}$ at any receptor located at

Detailed calculation of simulated concentration was done using MS Excel.

$\mathrm{x}=$ meters downwind, $\mathrm{y}$ meters crosswind and $\mathrm{z}$ meters above ground.

$\overline{\mathrm{u}}_{1}$ is the meteorological value of wind velocity calculated from equation (2).

The horizontal and vertical spreading coefficients $\left(\sigma_{\mathrm{y}} \& \sigma_{\mathrm{z}}\right)$ are obtained from the Pasquill stability class represented in Table 3and Table 4. 
Table 3: Pasquill stability class for obtaining ambient temperature gradient (Beychok, 2005). PASQUILL STABILITY CLASS

\section{AMBIENT TEMPERATURE GRADIENT} $\left({ }^{\circ} \mathrm{F} / 1000 \mathrm{FEET}\right)$

\begin{tabular}{lc}
\hline A - Very unstable & Less than -10.4 \\
B - Unstable & -10.4 to -9.9 \\
C - Slightly unstable & -9.3 to -8.2 \\
D - Neutral & -8.2 to -2.7 \\
E - Slightly stable & -2.7 to 8.2 \\
F - Stable & Greater than 8.2
\end{tabular}

\begin{tabular}{|c|c|c|c|c|c|c|}
\hline \multicolumn{7}{|c|}{ Table 4: Pasquill stability class for obtaining $\sigma_{\mathrm{y}} \& \sigma_{\mathrm{z}}$ (Beychok, 2005). } \\
\hline Pasquill & \multicolumn{3}{|c|}{ For obtaining $\sigma_{\mathrm{y}}$} & \multicolumn{3}{|c|}{ For obtaining $\sigma_{\mathrm{z}}$} \\
\hline $\begin{array}{l}\text { Stability } \\
\text { class }\end{array}$ & I & $\mathrm{J}$ & $\mathrm{K}$ & I & $\mathrm{J}$ & $\mathrm{K}$ \\
\hline $\mathrm{A}$ & 6.035 & 2.1097 & 0.2770 & 5.3570 & 0.8828 & -0.0076 \\
\hline $\mathrm{B}$ & 4.694 & 1.0629 & 0.0136 & 5.0580 & 0.9024 & -0.0096 \\
\hline $\mathrm{C}$ & 4.110 & 0.9201 & -0.0020 & 4.6510 & 0.9181 & -0.0076 \\
\hline $\mathrm{D}$ & 3.414 & 0.7371 & -0.0316 & 4.2300 & 0.9222 & -0.0087 \\
\hline $\mathrm{E}$ & 3.057 & 0.6794 & -0.0450 & 3.9220 & 0.9222 & -0.0064 \\
\hline $\mathrm{F}$ & 2.621 & 0.6564 & -0.0540 & 3.5330 & 0.9191 & -0.0070 \\
\hline
\end{tabular}

The most faithful representation of dispersion coefficients $\sigma_{\mathrm{y}} \& \sigma_{\mathrm{z}}$ are the equation published by McMullen (Beychok, 2005).

$\sigma=\exp \left[\mathrm{I}+\mathrm{J} \operatorname{Inx}+\mathrm{K}(\operatorname{Inx})^{2}\right]$

Where $\sigma$ is the rural dispersion coefficient, metres $(\mathrm{m})$.

$\mathrm{x}$ is the downwind distance, $\mathrm{km}$.

$\exp [\mathrm{a}]=(2.71828)^{\mathrm{a}}$.

The average ambient air temperature recorded in the community is $30^{\circ} \mathrm{C}$ (Smidth, 2006).

$\mathrm{T}=[1.8 * 30+32]^{\circ} \mathrm{F}=86^{\circ} \mathrm{F}$

Thus, from Table 3 it is slightly stable (E) from the pasquill stability class. For a distance of $5 \mathrm{~km}$

$\sigma_{\mathrm{z}}=\exp \left[3.057+0.674 * \operatorname{In} 5.0-0.045 *(\operatorname{In} 5.0)^{2}\right]=55.99 \mathrm{~m}$

Since the Gaussian is most accurate for a distance of $100 \mathrm{~m}-2000 \mathrm{~m}$ (Beychok, 2005)

$\sigma_{\mathrm{z}}=\exp \left[3.057+0.674 * \operatorname{In} 2.0-0.045 *(\operatorname{In} 2.0)^{2}\right]=33.32 \mathrm{~m}$

\subsubsection{Vertical Dispersion}

The generalized Gaussian dispersion equation is applicable from the emission source to some downwind distance, $\mathrm{X}_{\mathrm{L}}$ at which the mixing height (which is the distance from the ground to the base of an

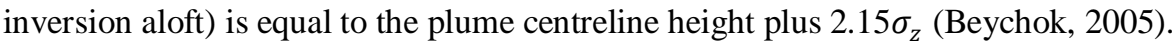

Height of inversion lid, $\mathrm{L}=\mathrm{H}_{\mathrm{e}}+2.15 \sigma_{z}$

The value 2.15 is the number of standard deviations from the plume centreline to the point where the pollutant concentration is 10percent of that at the plume centreline (Rao, 2006). The ratio $\left(\frac{\sigma_{Z}}{L}\right)$ is a measure of the downwind distance from the source as a fraction of the inversion lid height (i.e., the vertical mixing depth).

Thus, on an average value of $\mathrm{L}=2 \mathrm{H}_{\mathrm{s}}$, Where $\mathrm{H}_{\mathrm{s}}$ is the stack height

The cement mill stack height is $=57.2 \mathrm{~m}$ (Smidth, 2006).

$\mathrm{H}_{\mathrm{s}}=57.2 \mathrm{~m}$

$\left(\frac{\sigma_{\mathrm{z}}}{\mathrm{L}}\right)_{2 \mathrm{Km}}=\frac{33.32}{114.4}<1.0$

$\left(\frac{\sigma_{\mathrm{z}}}{\mathrm{L}}\right)_{5 \mathrm{Km}}=\frac{55.99}{114.4}<1.0 \quad$ And $\mathrm{H}_{\mathrm{e}}>\sigma_{\mathrm{z}}$

For $\sigma_{\mathrm{z}}$ calculated on the farthest distance $\left(\frac{\sigma_{\mathrm{z}}}{\mathrm{L}}\right)<1.0$.

Shum et al. derived a special form of equation for ground - level concentration $(z=0)$ when the vertical dispersion parameter is evaluated only for $\mathrm{m}=0$ and $\mathrm{m}=1$. Their special form includes:

$\mathrm{g}_{1}+\mathrm{g}_{2}=2 \exp \left\{-\frac{1}{2}\left(\frac{\mathrm{H}_{\mathrm{e}}}{\sigma_{\mathrm{z}}}\right)^{2}\right\}$
$\mathrm{g}_{3}=2\left\{\exp \left[-\frac{1}{2}\left(\frac{-\mathrm{H}_{\mathrm{e}}+2 \mathrm{~L}}{\sigma_{\mathrm{z}}}\right)^{2}\right]+\exp \left[-\frac{1}{2}\left(\frac{-\mathrm{H}_{\mathrm{e}}-2 \mathrm{~L}}{\sigma_{\mathrm{z}}}\right)^{2}\right]\right\}$ 
The use of $\mathrm{m}=0$ and $\mathrm{m}=1$ is adequate only for these receptor distances at which $\left(\frac{\sigma_{z}}{L}\right)$ is 1.0 or less (Beychok, 2005).

For this case of $\left(\frac{\sigma_{\mathrm{Z}}}{\mathrm{L}}\right)<1.0$, the Gaussian model equation is given a;

$\mathrm{C}=\frac{\mathrm{Q}}{\overline{\mathrm{u}}} \cdot \frac{\mathrm{W}}{\sigma_{\mathrm{y}} \sqrt{2 \pi}} \cdot \frac{\mathrm{g}_{1}+\mathrm{g}_{2}+\mathrm{g}_{3}}{\sigma_{\mathrm{z}} \sqrt{2 \pi}}$

Where $\mathrm{g}_{1}+\mathrm{g}_{2}=2 \exp \left\{-\frac{1}{2}\left(\frac{\mathrm{H}_{\mathrm{e}}}{\sigma_{\mathrm{z}}}\right)^{2}\right\}$ and

$\mathrm{g}_{3}=2\left\{\exp \left[-\frac{1}{2}\left(\frac{-\mathrm{H}_{\mathrm{e}}+2 \mathrm{~L}}{\sigma_{\mathrm{z}}}\right)^{2}\right]+\exp \left[-\frac{1}{2}\left(\frac{-\mathrm{H}_{\mathrm{e}}-2 \mathrm{~L}}{\sigma_{\mathrm{z}}}\right)^{2}\right]\right\}$

$\sigma=\exp \left[\mathrm{I}+\mathrm{J} \operatorname{Inx}+\mathrm{K}(\operatorname{In} \mathrm{x})^{2}\right]$

$\sigma_{\mathrm{y}}=\exp \left[3.922+0.9222 * \operatorname{Inx}-0.0064 *(\operatorname{Inx})^{2}\right]$

$\sigma_{\mathrm{z}}=\exp \left[3.057+0.6794 * \operatorname{Inx}-0.045 *(\operatorname{Inx})^{2}\right]$

The Effective stack height $\left(\mathrm{H}_{\mathrm{e}}\right)$ is given as

$\mathrm{H}_{\mathrm{e}}=\mathrm{H}_{\mathrm{s}}+\Delta \mathrm{H}$

Where $\mathrm{H}_{\mathrm{s}}=$ Stack height, $(\mathrm{m})$.

$\mathrm{H}_{\mathrm{s}}=57.2 \mathrm{~m}$

$\Delta \mathrm{H}=$ Plume rise, $(\mathrm{m})$

For stable atmospheric condition,

$\Delta \mathrm{H}=1.6 * \mathrm{~F}^{1 / 3} * \mathrm{X}^{2 / 3} * \overline{\mathrm{u}}^{-1}$

$\Delta \mathrm{H}_{\max }=2.9 *\left(\frac{\mathrm{F}}{\overline{\mathrm{u} S}}\right)^{1 / 3}$

for $\mathrm{x}<2.4 \bar{u} * \mathrm{~S}^{-1 / 2}$

for $\mathrm{x}>2.4 \bar{u} * \mathrm{~S}^{-1 / 2}$

$\mathrm{F}=$ Briggs Buoyancy flux parameter, $\mathrm{m}^{4} / \mathrm{s}^{3}$.

$\mathrm{F}=\left(7.56 * 10^{-7}\right) \mathrm{Q}_{\mathrm{c}}$

$\Delta \mathrm{H}_{\text {max }}=$ Maximum plume rise, $\mathrm{m}$.

$\Delta \mathrm{H}=$ Plume rise for first $\&$ transitional stage, $\mathrm{m}$

$\mathrm{X}=$ Downwind distance from stack, $\mathrm{m}$.

$\mathrm{Q}_{\mathrm{c}}=$ Stack gas sensible heat of emission.

$\mathrm{Q}_{\mathrm{c}}=\mathrm{Cp}_{\mathrm{s}} * \rho_{\mathrm{s}} * \mathrm{~V}_{\mathrm{s}} *\left(\mathrm{~T}_{\mathrm{s}}-\mathrm{T}_{\mathrm{a}}\right)$

$\rho_{\mathrm{s}}=\rho_{\mathrm{a}} \cdot \frac{\mathrm{T}_{\mathrm{a}}}{\mathrm{T}_{\mathrm{s}}}$ (Beychok, 1995)

$\mathrm{Cp}_{\mathrm{s}}=$ the specific heat capacity of stack gas, $(\mathrm{J} / \mathrm{kg} . \mathrm{K})$.

$\rho_{\mathrm{a}}=$ the ambient air density, $\left(\mathrm{Kg} / \mathrm{Nm}^{3}\right)$.

$\mathrm{T}_{\mathrm{a}}=$ the ambient air temperature, $\left({ }^{\mathrm{o}} \mathrm{K}\right)$.

$\mathrm{T}_{\mathrm{s}}=$ the stack gas temperature, $\left({ }^{\circ} \mathrm{K}\right)$.

$\mathrm{V}_{\mathrm{s}}=$ the stack gas flow, $\left(\mathrm{m}^{3} / \mathrm{s}\right)$.

For a stack heat emission of any size in stable atmospheric conditions, the maximum plume rise was defined as occurring at the point where $\mathrm{X} \approx 2.4 \overline{\mathrm{u}} * \mathrm{~S}^{-1 / 2}$ (Beychok, 2005).

$\mathrm{S}$ is the Brigg's stability parameter, $\mathrm{sec}^{-2}$.

The Brigg's stability parameter, $\mathrm{S}$ is a measure of the effect of atmospheric turbulence upon the rise of a stack gas plume.

$\mathrm{S}=\left(\frac{\mathrm{g}}{\mathrm{T}_{\mathrm{a}}}\right) * \frac{\mathrm{d} \theta}{\mathrm{dz}}$

$\mathrm{g}=9.807 \mathrm{~m} / \mathrm{s}^{2}$

$\frac{\mathrm{d} \theta}{\mathrm{dz}}=$ the potential temperature gradient, $\left({ }^{\mathrm{o}} \mathrm{K} / \mathrm{m}\right)$

Table 5 lists the defining ambient temperature gradients for each of the Pasquill stability classes, as well as their equivalent potential temperature gradients. 
Table 5: Potential temperature gradient (Beychok, 2005).

\begin{tabular}{l|c|c|c}
\hline \multirow{2}{*}{$\begin{array}{l}\text { Stability } \\
\text { Class }\end{array}$} & $\begin{array}{c}\text { Ambient } \\
\text { gradient }\end{array}$ & $\begin{array}{l}\text { Ambient lapse } \\
\text { rate }\end{array}$ & Potential gradient \\
\cline { 2 - 4 } & $\frac{\mathrm{dT}}{\mathrm{dz}}$ & $\Gamma$ & $\frac{\mathrm{d} \theta}{\mathrm{dz}}=\left(\frac{\mathrm{dT}}{\mathrm{dz}}-\Gamma\right)$ \\
\cline { 2 - 4 } & $\left(\frac{{ }^{\circ} \mathrm{F}}{1000 \mathrm{ft}}\right)$ & $\left(\frac{{ }^{\circ} \mathrm{F}}{1000 \mathrm{ft}}\right)$ & $\left(\frac{{ }^{\circ} \mathrm{F}}{1000 \mathrm{ft}}\right)$ \\
\hline A - Very unstable & $<-10.4$ & -5.5 & $<-4.9$ \\
B - Unstable & -9.9 & -5.5 & -4.4 \\
C - Slightly unstable & -8.8 & -5.5 & -3.3 \\
D - Neutral & -5.5 & -5.5 & 0.0 \\
E - Slightly stable & 2.8 & -5.5 & 8.3 \\
F- Stable & $>8.2$ & -5.5 & $>13.7$ \\
\hline
\end{tabular}

Hence, the downwind concentration of particulate matter emitted from each of the cement mill stack is calculated using the formulated Gaussian Dispersion equation given below:

$$
\begin{aligned}
& \mathrm{C}_{1}=\left\{\frac{(1 / \varepsilon) \rho_{\mathrm{p}} \mathrm{V}_{\mathrm{s} 1}}{\overline{\mathrm{u}}_{1} \sigma_{\mathrm{y}} \sqrt{2 \pi}}\right\} \cdot \exp \left[\frac{-1}{2}\left(\frac{\mathrm{y}}{\sigma_{\mathrm{y}}}\right)^{2}\right] \cdot\left[\frac{\left(\mathrm{g}_{1}+\mathrm{g}_{2}+\mathrm{g}_{3}\right)_{1}}{\sigma_{\mathrm{z}} \sqrt{2 \pi}}\right] \\
& \mathrm{C}_{2}=\left\{\frac{(1 / \varepsilon) \rho_{\mathrm{p}} \mathrm{V}_{\mathrm{s} 2}}{\overline{\mathrm{u}}_{1} \sigma_{\mathrm{y}} \sqrt{2 \pi}}\right\} \cdot \exp \left[\frac{-1}{2}\left(\frac{\mathrm{y}}{\sigma_{\mathrm{y}}}\right)^{2}\right] \cdot\left[\frac{\left(\mathrm{g}_{1}+\mathrm{g}_{2}+\mathrm{g}_{3}\right)_{2}}{\sigma_{\mathrm{z}} \sqrt{2 \pi}}\right] \\
& \mathrm{C}_{3}=\left\{\frac{(1 / \varepsilon) \rho_{\mathrm{p}} \mathrm{V}_{\mathrm{s} 3}}{\overline{\mathrm{u}}_{1} \sigma_{\mathrm{y}} \sqrt{2 \pi}}\right\} \cdot \exp \left[\frac{-1}{2}\left(\frac{\mathrm{y}}{\sigma_{\mathrm{y}}}\right)^{2}\right] \cdot\left[\frac{\left(\mathrm{g}_{1}+\mathrm{g}_{2}+\mathrm{g}_{3}\right)_{3}}{\sigma_{\mathrm{z}} \sqrt{2 \pi}}\right] \\
& \mathrm{C}_{4}=\left\{\frac{(1 / \varepsilon) \rho_{\mathrm{p}} \mathrm{V}_{\mathrm{s}}}{\overline{\mathrm{u}}_{1} \sigma_{\mathrm{y}} \sqrt{2 \pi}}\right\} \cdot \exp \left[\frac{-1}{2}\left(\frac{\mathrm{y}}{\sigma_{\mathrm{y}}}\right)^{2}\right] \cdot\left[\frac{\left(\mathrm{g}_{1}+\mathrm{g}_{2}+\mathrm{g}_{3}\right)_{4}}{\sigma_{\mathrm{z}} \sqrt{2 \pi}}\right]
\end{aligned}
$$

\subsubsection{Limits to the Formulated Plume Model}

Though, statistical analysis within specified Gaussian distances $(100-200 \mathrm{~m})$ yield better predictive values. Any farther distance above $200 \mathrm{~m}$ is likely to far from the experimental result. This is due to local terrain variability, deposition, washout and interception of tree and buildings. Also, at a distance below 100 that is likely to be within the plant, the experimental result is so high compared with the predictive result. This is due to fugitive emissions from several points in the plant like Parking plant, Mix storage, homogenisation department etc. Since, the Gaussian model equation can best be used in calculating hourly particulate concentration (Holmes and Morawska, 2006). The experimental values obtained were based on hourly pollutant of particulate concentrations.

\section{Results And Discsussion}

Suspended Particulate Matter (SPM) is the most significant source of air pollution affecting many developed and populated cities in the world. Particulate matter, one of the six criteria pollutants regulated by the Nigerian Federal Ministry of Environmental (FMEv) and the United State National Ambient Air Quality Standard (NAAQS), is the generic term for dust and other diverse type of particles in the air. Due to the continuous growth of industries the deterioration of air quality in urban areas has provided the impetus for comprehensive modeling of air quality. Emissions from industrial stacks are regulated to protect human and environmental health (EIA, 2008). The emission of particulate matter has been an integral part of the operations associated with the production of cement in Nigeria. The data collated from a cement plant in Nigeria are presented in graphical forms.

Figures 2 and 3 represent the results of field measurements and simulations taken on $6^{\text {th }}$ August, 2009 and $8^{\text {th }}$ April, 2010 for cement mill stack 1 at 96 and 95\% bagfilter efficiency respectively. 


\section{Cement Mill Stack - 1}

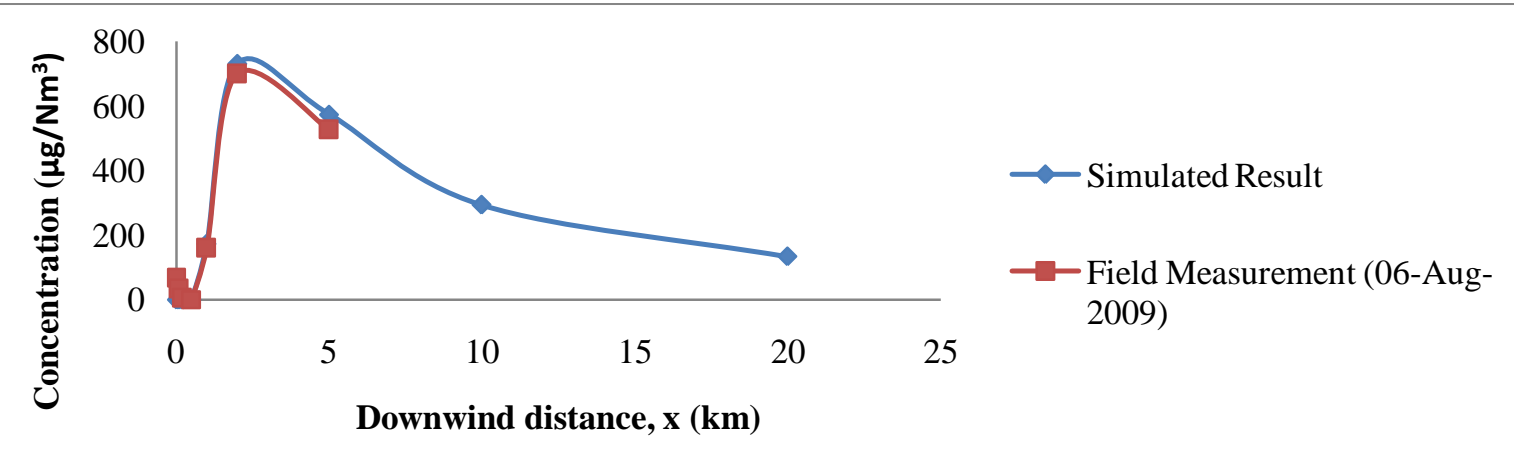

Figure 2: Field and Simulated data Vs Downwind distance for stack 1 at $96 \%$ bagfilter efficiency.

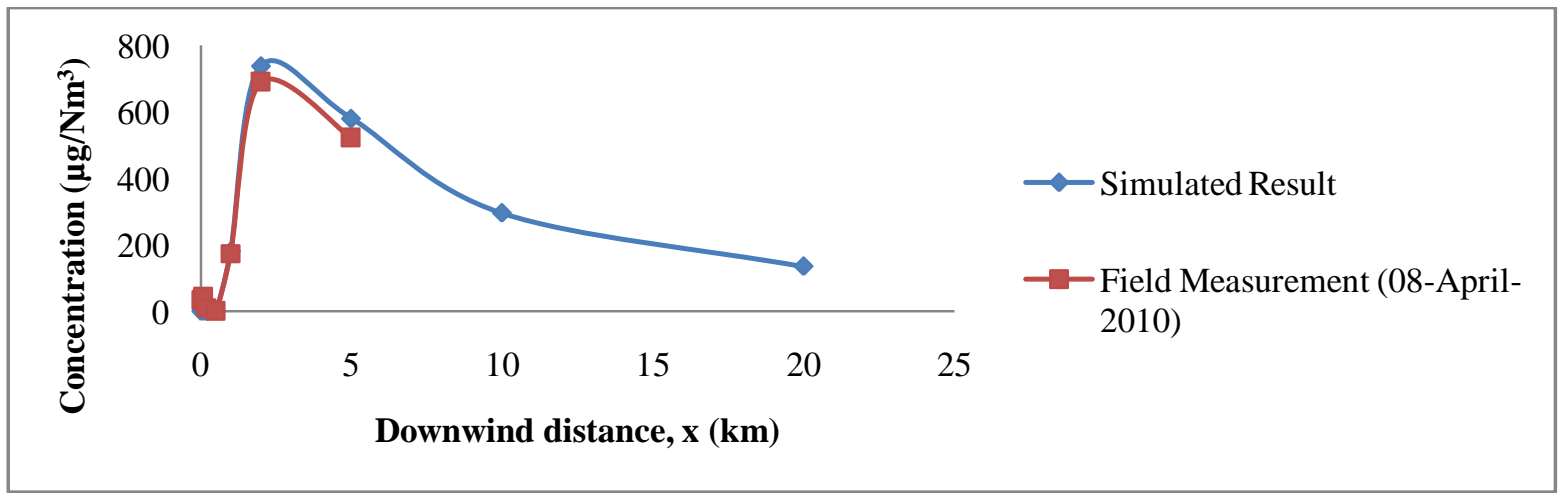

Figure 3: Field and Simulated data Vs Downwind distance for stack 1 at $95 \%$ bagfilter efficiency.

Figures 4, 5 and 6 represent the results of field measurements and simulations taken on $23^{\text {rd }}$ July, 2009, $7^{\text {th }}$ May, 2010 and $19^{\text {th }}$ August, 2010 for cement mill stack 2 at 98,97 and 94\% bagfilter efficiency respectively.

\section{Cement Mill Stack - 2}

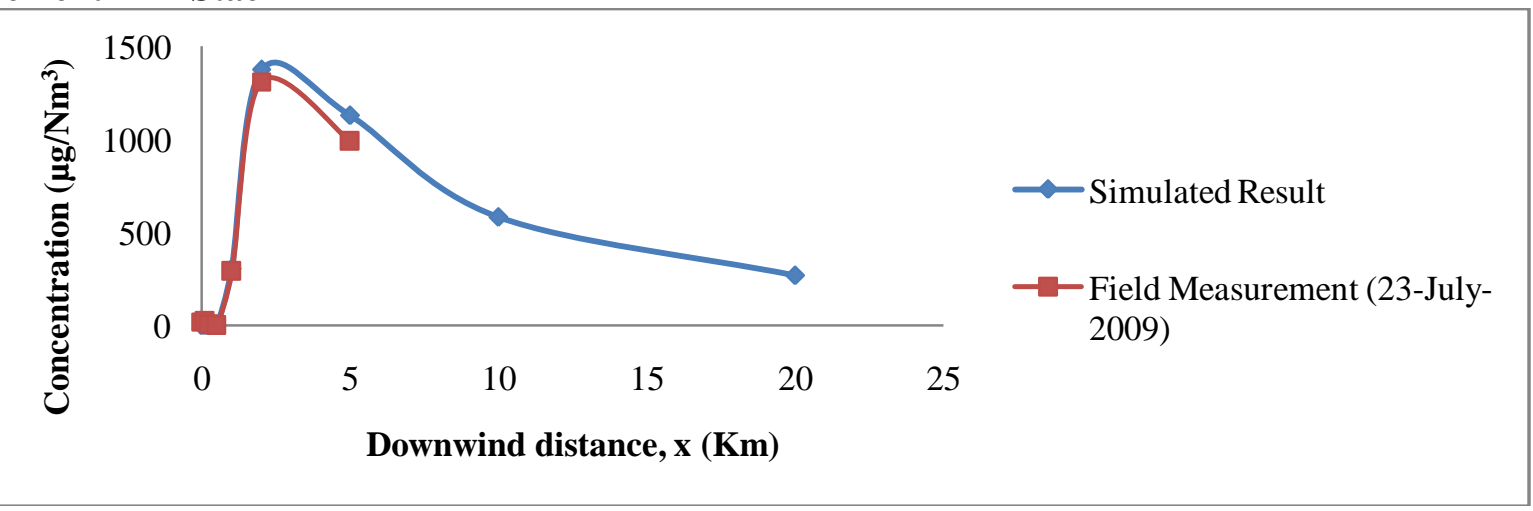

Figure 4: Field and Simulated data Vs Downwind distance for stack 2 at $98 \%$ bagfilter efficiency. 


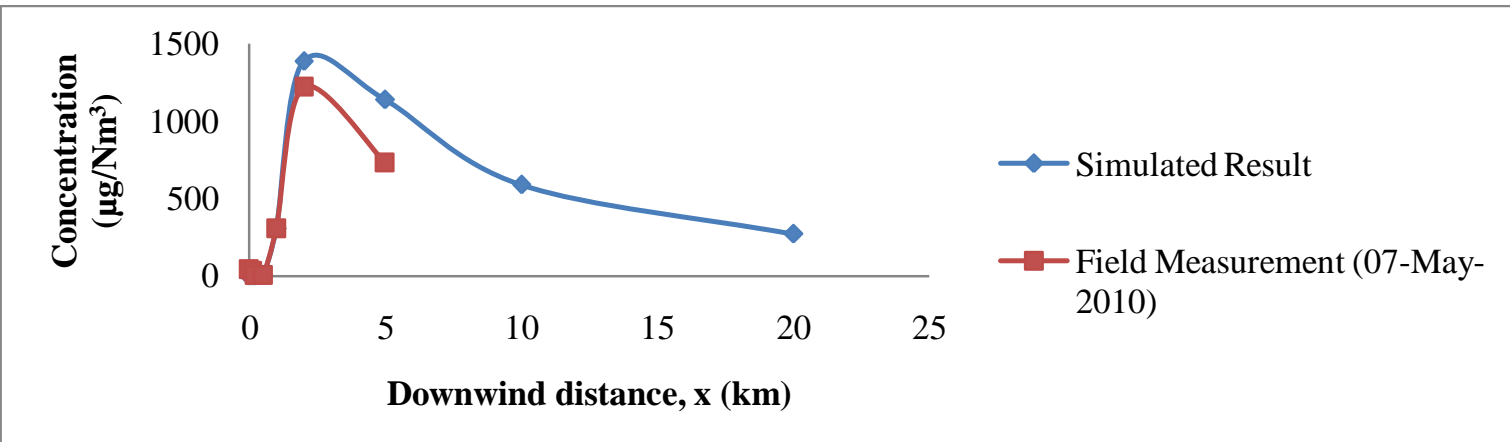

Figure 5: Field and Simulated data Vs Downwind distance for stack 2 at $97 \%$ bagfilter efficiency.

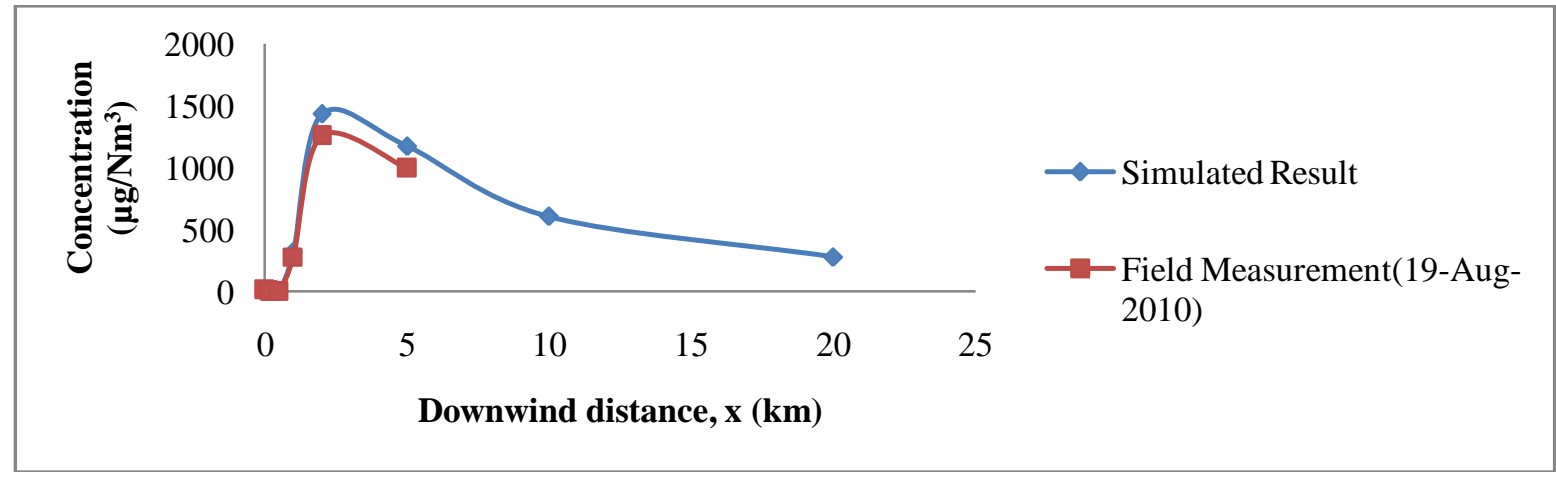

Figure 6: Field and Simulated data Vs Downwind distance for stack 2 at $94 \%$ bagfilter efficiency.

Figures 7 and 8 represent the results of field measurements and simulations taken on $21^{\text {st }}$ August, 2009 and $11^{\text {th }}$ March, 2010 for cement mill stack 3 at 97 and 94\% Bagfilter efficiency respectively.

Cement Mill Stack - 3

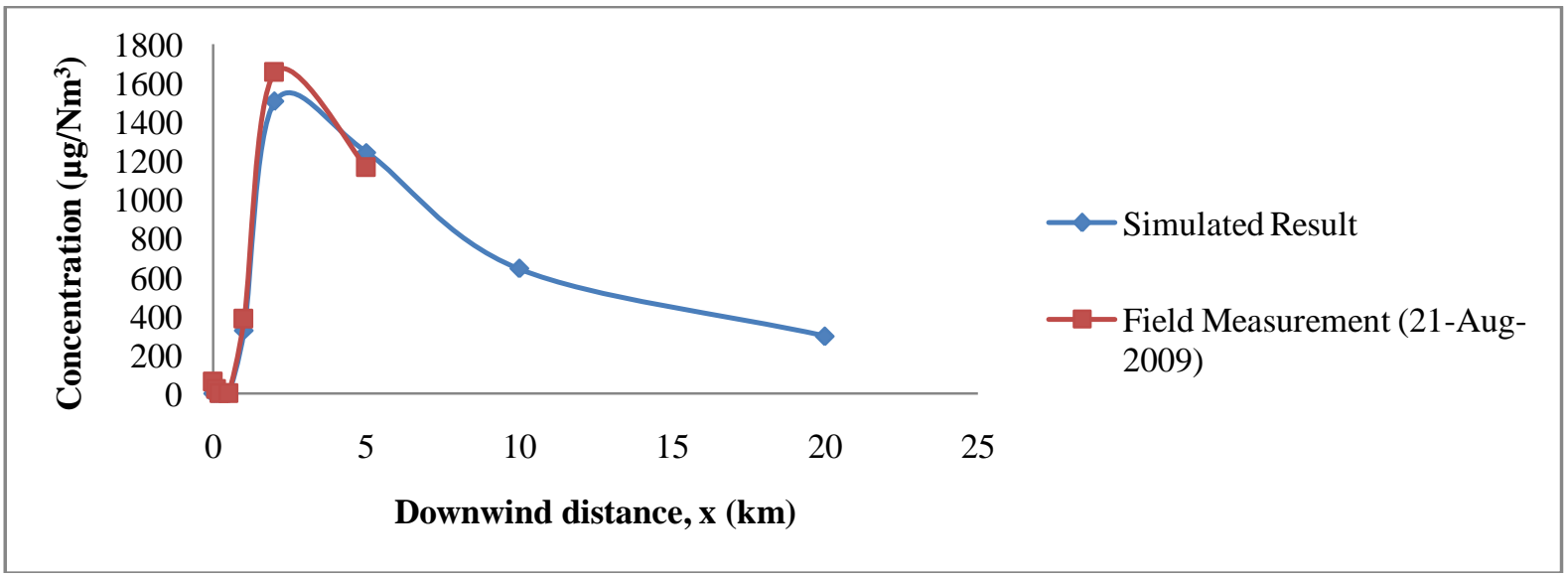

Figure 7: Field and Simulated data Vs Downwind distance for stack 3 at $97 \%$ bagfilter efficiency. 


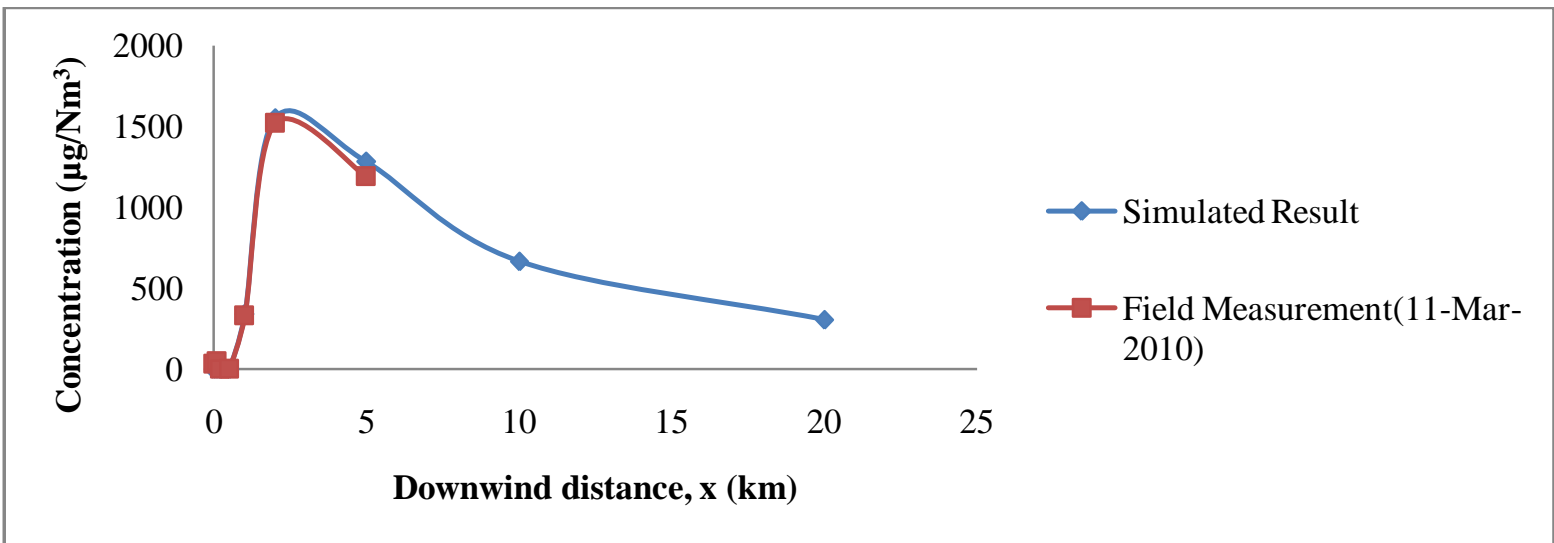

Figure 8: Field and Simulated data Vs Downwind distance for stack 3 at $94 \%$ bagfilter efficiency.

Figures 9, 10, 11, 12 and 13 represent the results of field measurements and simulations taken on $3^{\text {rd }}$ July, $2009,10^{\text {th }}$ September, 2009, $22^{\text {nd }}$ October, 2009, $29^{\text {th }}$ January, 2010, and $8^{\text {th }}$ July, 2010 for cement mill stack 4 at 96, 96, 98, 94 and $97 \%$ bagfilter efficiency respectively.

Cement Mill Stack - 4

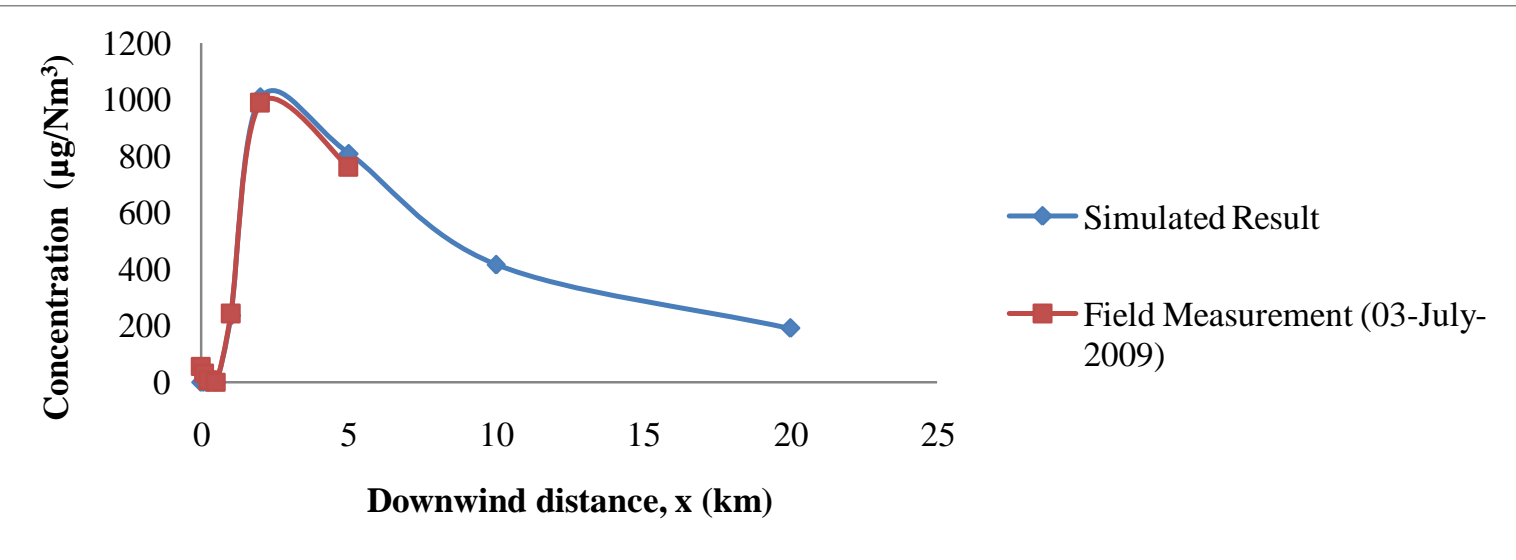

Figure 9: Field and Simulated data Vs Downwind distance for stack 4 at $96 \%$ bagfilter efficiency.

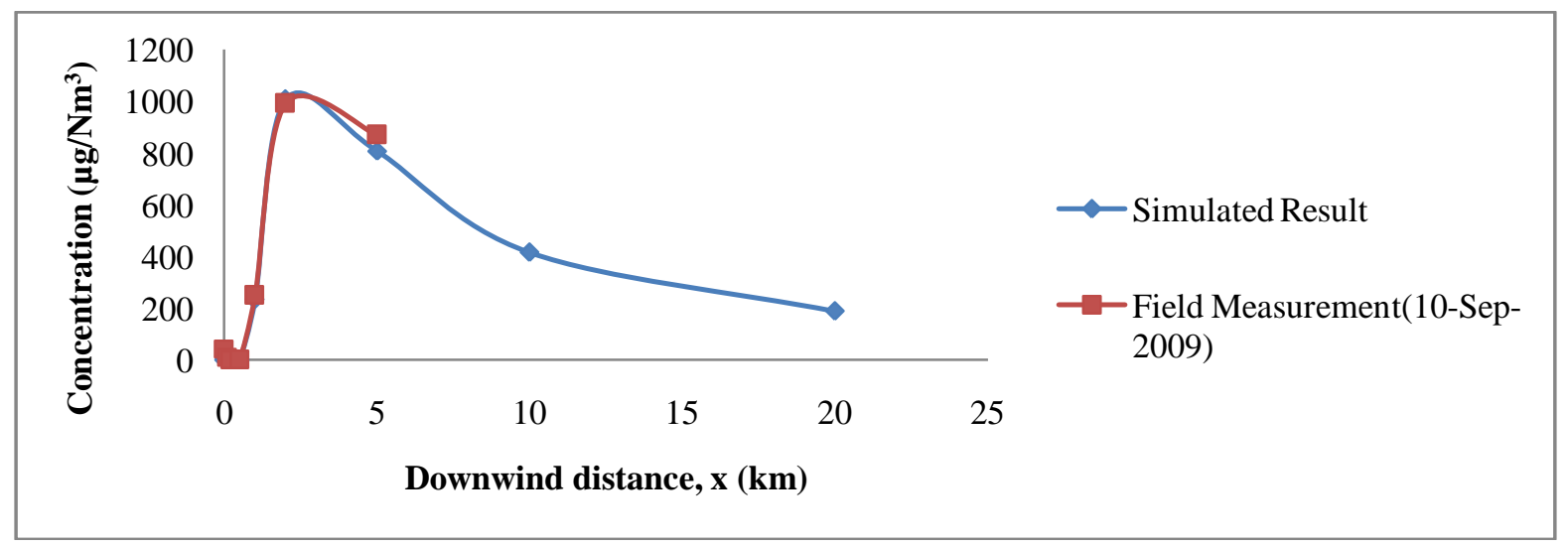

Figure 10: Field and Simulated data Vs Downwind distance for stack 4 at $96 \%$ bagfilter efficiency. 


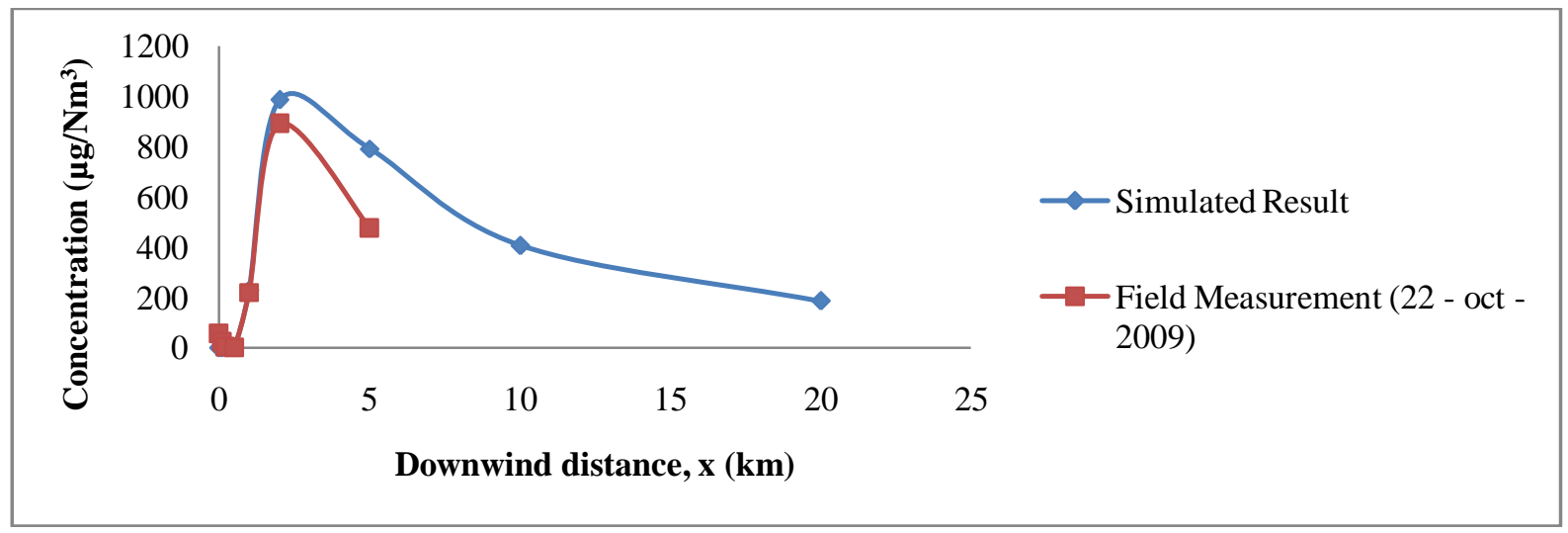

Figure 11: Field and Simulated data Vs Downwind distance for stack 4 at $98 \%$ bagfilter efficiency.

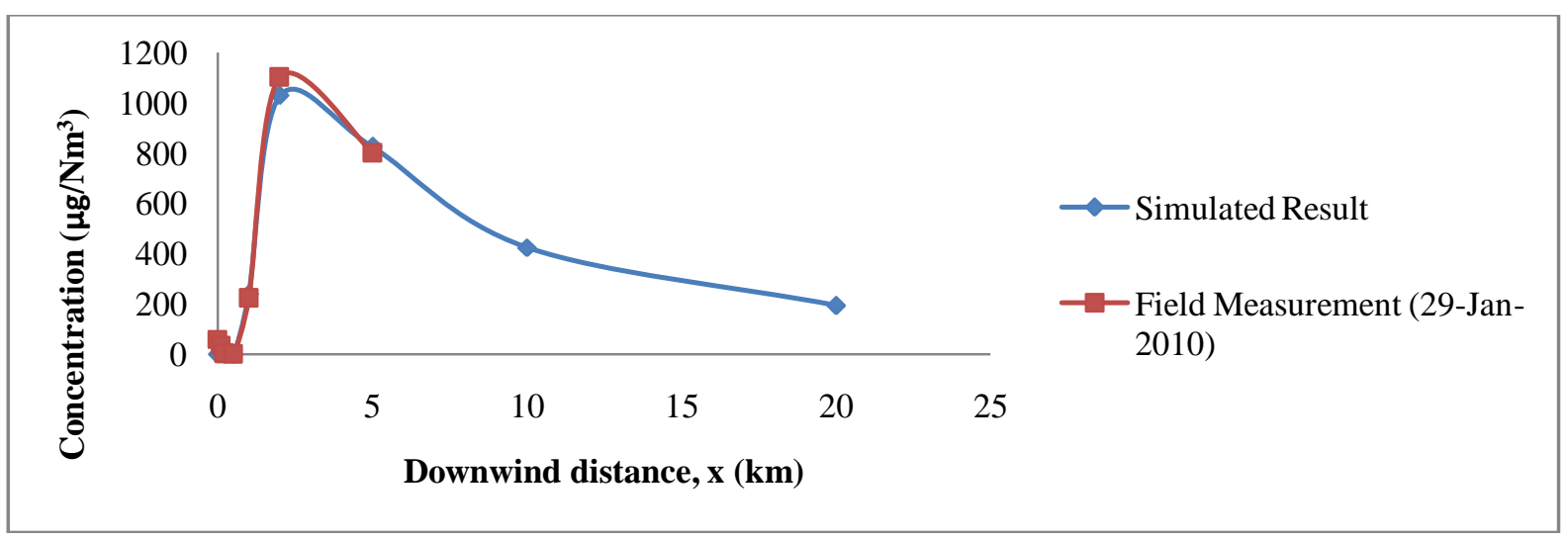

Figure 12: Field and Simulated data Vs Downwind distance for stack 4 at $94 \%$ bagfilter efficiency.

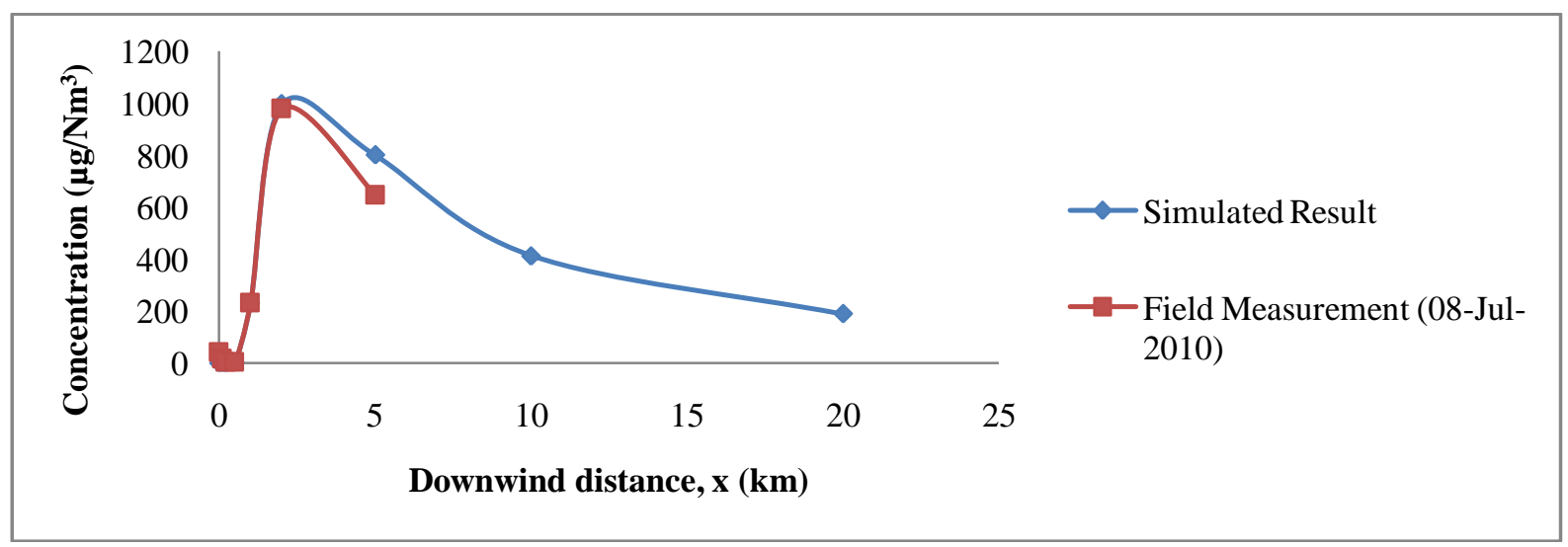

Figure 13: Field and Simulated data Vs Downwind distance for stack 4 at $97 \%$ bagfilter efficiency.

It is observed from Figure $2-13$ that the concentration of particulate matter varies from station to station and from month to month. This is attributed to the fact that the production rate varies for different cement mill, differential pressures in each of the cement mills and bagfilters and the difference in volume of pollutants emitted from the stacks. It is also observed that at a downwind distance of $0-200 \mathrm{~m}$ away from the source, the experimental and simulated result in Figure 2 - 13, does not agree with each other. This is due to fugitive emissions within the plant i.e from the mix-storage department, packing plant, cement silo, kiln, and clinker extraction area. It is also observed that the simulated result agrees with the experimental result at a downwind distance of $200 \mathrm{~m}$ to $2,000 \mathrm{~m}$. However, one of the limitations of Gaussian model is that it is particularly suitable to accurately predict the downwind concentration of air pollutants from a source at a distance of $100 \mathrm{~m}-2,000 \mathrm{~m}$ because it assumes a constant wind velocity (Beychok, 2005). 
The particulate concentration in the ambient environment from various cement mill stack and those of simulated results presented in Figure 2 to 13 show that the particulate concentration increases between $0-$ $2.5 \mathrm{Km}$ thereafter it decreases at further downwind distance. The high effective stack height is an indication that the particulates will travel some distances far away from the stack before reaching the ground. The significant decrease in the particulate concentrations at further downwind distance is due to the spreading of the plume, wind velocity, interception of trees and buildings, absorption, deposition and washout (Rao, 2006). Also, the difference in volume of emitted pollutants and bagfilter efficiency for different cement mill plants are another factor that is responsible for the difference in particulate concentration at different source. It could be justified from the model equation that the meteorological concentration is inversely proportional to the bagfilter efficiency but has direct effect with increase in source volume of emitted pollutants.

The validity of the model was checked by performing some basic statistically analyses of the field and simulated results to obtain their difference in variance, mean deviation and standard errors for a valid Gaussian distance of $200-2,000 \mathrm{~m}$ using the least square method of normal equation. On comparison of the variance and standard error of field measurements and simulated results indicate $92 \%$ accuracy and minimal value of mean deviation (0.00018). The disagreement between the simulated results and the field measurements is because most of the assumptions made in formulation of the predictive model were not under the direct control of the experiment (Abdulkareem and Odigure, 2009).

Graphical illustration of simulated results at a distance of $100 \mathrm{~km}$ away from the cement mill stacks are presented in Figure 14 and Figure 15. This was done to examine the behaviour and impacts of the pollutant on the farther environments. The simulated results show that the particulate concentration decreases after the maximum ground level has been recorded. This is due to deposition, spreading of plume and low value of wind velocity from source (Rao, 2002). The concentrations calculated at these farthest distances are below the world health and Nigerian Federal Ministry of Environmental standard and is recommended for human activities and settlement.

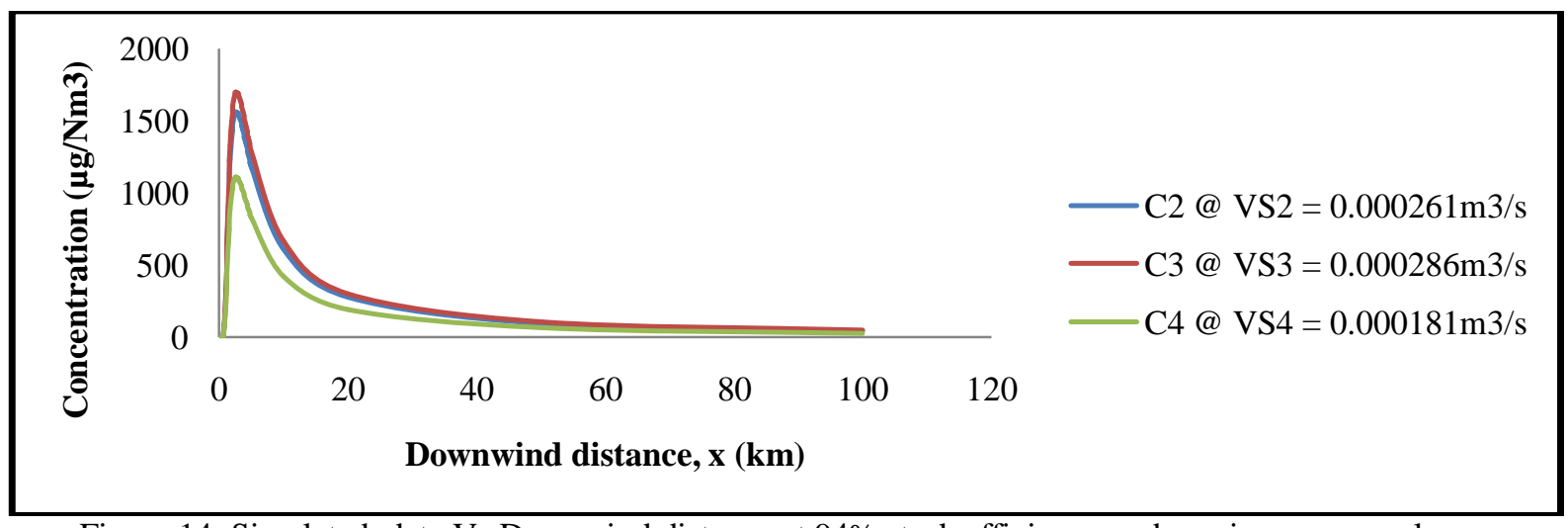

Figure 14: Simulated data Vs Downwind distance at 94\% stack efficiency and varying source volume flowrate

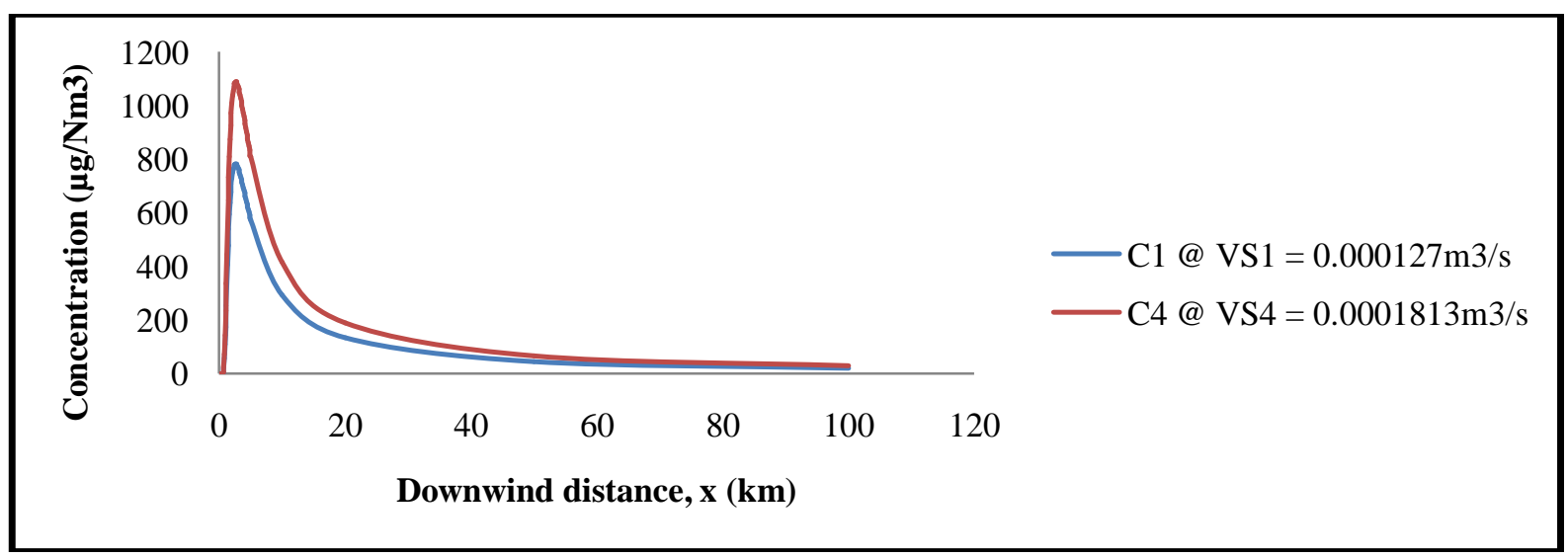

Figure 15: Simulated data Vs Downwind distance at 96\% bagfilter efficiency and varying source volume flowrate. 


\section{Conclusion}

A detailed dispersion model was formulated based on the adaptation of Gaussian distribution equation, to quantify the concentration of particulate matter at any downwind distance from a cement mill stack. The model equation that satisfactorily predicts the particulate concentration as function of bagfilter efficiency, crosswind distance, downwind distance, volume of emitting particulates, stack temperature, particle density, atmospheric stability, wind velocity, spreading coefficients, and vertical dispersion parameters is given by $\mathrm{C}=$ $\left\{\frac{(1 / \varepsilon) \rho_{\mathrm{p}} \mathrm{V}_{\mathrm{s}}}{\overline{\mathrm{u}}_{1} \sigma_{\mathrm{y}} \sqrt{2 \pi}}\right\} \cdot \exp \left[\frac{-1}{2}\left(\frac{\mathrm{y}}{\sigma_{\mathrm{y}}}\right)^{2}\right] \cdot\left[\frac{\mathrm{g}_{1}+\mathrm{g}_{2}+\mathrm{g}_{3}}{\sigma_{\mathrm{z}} \sqrt{2} \pi}\right]$. It was observed statistically the simulated result is approximately $92 \%$ closer to the experimental results with a average minimum deviation value of 0.00018 . Also, both the simulated results and the field measurements of this work show that the particulate concentration in the ambient air in distances of $1.5-4.5 \mathrm{~km}$ from the stack is higher than the World Health Organisation (WHO) guideline of annual average value of $260 \mu \mathrm{g} / \mathrm{Nm}^{3}$. Also, concentration of particulate matter in ambient air in distances of 2.0 - 4.0km from the stack is higher than the Nigeria Federal Ministry of Environmental (FMEv) guideline of annual average value of $500 \mu \mathrm{g} / \mathrm{Nm}^{3}$. Due to other fugitive emissions from cement plants, a simulated safety distance beyond $7.0 \mathrm{~km}$ from the plant is recommended for human settlement and activities.

\section{References}

[1] Abdulkareem, AS and Odigure, JO (2009). Predictive Model for Pollutant Dispersion from Gas Flaring: A Case Study of Oil Producing Area of Nigeria. Energy Sources, Part A: Recovery, Utilization, and Environmental Effects, 31:12, 1004-1015.

[2] Armistead, GR (1988). Mathematical Modeling of the Effect of Emission Sources on Atmosphere Pollutant Concentration. Institute of National Academy Press, Washington D.C.

[3] Bala, IA (2003). Assessment of $\mathrm{CO}, \mathrm{CO}_{2}$ and Suspended Particulate Matter Emissions. B.Eng, Thesis, Department of Chemical Engineering, Federal University of Technology, Yola, Nigeria.

[4] Beychok, MR (1995). Fundamental of Stack Gas Dispersion. $3^{\text {rd }}$ Edition, Irvin, California.

[5] Beychok, MR (2005). Fundamental of Stack Gas Dispersion. $4^{\text {th }}$ Edition, authors-Published ISBN $09644588-02$.

[6] EIA, (2008). Environmental Impact Assessment Report. Industrial Hygiene Services. Environmental Division, for Madhuvan Cement Industries, Junagadh.

[7] Holmes, NS and Morawska, L., (2006). A review of Dispersion Modelling and its Application to the Dispersion of Particles: An Overview of Different Dispersion Models Available. Atmospheric Environment. 40 (30):5902-5928.

[8] Karl, BS and Partha, RD (2000). Atmospheric Dispersion Modeling Compliance Guide. ISBN 0-07-058059-6. Printed and Bound by R.R Donnell.

[9] Rao, PV (2002). Textbook of Environmental Engineering. Prentice-Hall of India Private Limited, New Delhi.

[10] Rao, CS (2006). Environmental Pollution Control Engineering. Revised $2^{\text {nd }}$ edition, Chemical Engineering - Birla Institute of Technology and Science, Pilani. New Age International (P) Limited Publishers, New Delhi.

[11] Smidth, FL (2006). Cement Making Process.”Obajana Cement Plc. Lokoja, Kogi State, Nigeria.

[12] US EPA, (2004). United State Environmental Protection Agency. Inventory of U.S Greenhouse Gas Emissions and Sinks. Washington, D.C. EPA 430-R-04-003.

[13] Weber, GF and Schelkoph, GL (1990). Performance/durability evaluation of 3M Company's High-Temperature Nextel filter bags. Presented at the Eighth Symposium on The Transfer and Utilization of Particulate Control Technology, San Diego, California.

[14] WBCSD, (2005). World Business Council for Sustainable Development. Cement Sustainability Initiative. Draft for Discussion, PP $1-7$.

[15] www.elri-ng.org/newsandrelease2.html 1/December/2011-14:30

[16] www.slyfilters.com (05/February/2012-15:46) 